\title{
PENGARUH MODEL PEMBELAJARAN BERBASIS MASALAH DALAM MENINGKATKAN KEMAMPUAN PEMECAHAN MASALAH MATEMATIS SISWA SMP NEGERI 2 DEWANTARA
}

\author{
Ria Andriana ${ }^{1}$, Muliana $^{2}$, Yeni Listiana ${ }^{3 *}$ \\ Program Studi Pendidikan Matematika, Universitas Malikussaleh ${ }^{1,2,3}$ \\ 1riaandriana2045@gmail.com \\ 2muliana@unimal.ac.id \\ 3* yenilistiana@unimal.ac.id
}

\begin{abstract}
Abstrak
Penelitian ini bertujuan untuk mengetahui peningkatan kemampuan pemecahan masalah matematis siswa yang diterapkan melalui model pembelajaran berbasis masalah lebih baik daripada peningkatan kemampuan pemecahan masalah matematis siswa yang diterapkan melalui pembelajaran konvensional. Penelitian ini menggunakan pendekatan kuantitatif. Jenis penelitian yang digunakan adalah quasi eksperimental design dengan rancangan nonequivalent control group design. Teknik pemilihan sampel yaitu menggunakan teknik purposive sampling. Populasi dalam penelitian ini adalah seluruh siswa kelas VII SMPN 2 Dewantara, sedangkan yang menjadi sampelnya adalah dua kelas yaitu kelas VII-A sebagai kelas eksperimen dan kelas VII-B sebagai kelas kontrol. Pengambilan data dalam penelitian ini menggunakan tes dan obsevasi kegiatan guru dan siswa. Data dianalisis dengan menggunakan SPSS versi 18 dengan uji prasyarat menggunakan uji Mann-Whitney U-Test. Berdasarkan hasil analisis data menunjukkan bahwa skor rataan $\mathrm{N}$-gain siswa yang menerapkan model pembelajaran berbasis masalah sebesar 0,8381 (kategori tinggi) lebih tinggi dari siswa yang memperoleh pembelajaran konvensional sebesar 0,4191 (kategori sedang). Dari hasil uji Mann-Whitney U-Test di atas didapat nilai Asymp. Sig (2-tailed) yaitu $0,000<\alpha=0,05$. Hal ini menunjukkan bahwa peningkatan kemampuan pemecahan masalah matematis siswa yang menerapkan model pembelajaran berbasis masalah lebih baik secara signifikan daripada siswa yang hanya mendapat pembelajaran konvensional. Dan hal itu juga terlihat dari aktifitas guru sebesar 83,63\% (kategori sangat baik) dan aktivitas siswa sebesar $77,7 \%$ (kategori sangat baik) sehingga dapat disimpulkan bahwa selama kegiatan pembelajaran siswa dapat beradaptasi dengan model yang diajarkan sehingga didapatkan nilai yang meningkat.
\end{abstract}

Kata kunci: Kemampuan Pemecahan Masalah Matematis, Pembelajaran Berbasis Masalah, Garis dan Sudut

\section{Pendahuluan}

Menurut kurikulum 2013 tujuan dari pembelajaran matematika disekolah adalah untuk mengembangkan kemampuan-kemampuan yang dimiliki siswa, salah satunya yaitu 
kemampuan siswa dalam memahami masalah. National Council of Teacher of Matethematic (NCTM, 2000) menetapkan bahwa terdapat lima kemampuan yang harus dimiliki siswa dalam pembelajaran matematika, yakni: pemecahan masalah matematis (mathematical problem solving), komunikasi matematis (mathematical communication), penalaran matematis (mathematical reasoning), dan koneksi matematis (mathematical connection), dan representasi matematis (mathematical reprentation).

Salah satu kemampuan matematis yang harus dimiliki siswa bedasarkan tujuan pembelajaran adalah pemecahan masalah. Menurut Polya (Hendriana, Rohaeti, \& Sumarmo, 2018) pemecahan masalah adalah suatu usaha mencari jalan keluar dari suatu tujuan yang tidak begitu mudah dan segera dapat dicapai, sedangkan menurut pakar lain Sumarno (Hendriana, Rohaeti, \& Sumarmo, 2018) pemecahan masalah adalah suatu proses untuk mengatasi kesulitan yang ditemui untuk mencapai suatu tujuan yang dinginkan

Berdasarkan hasil observasi yang dilakukan peneliti dengan mewawancarai salah satu guru bidang studi matematika di SMPN 2 Dewantara, guru tersebut mengatakan bahwa kemampuan pemecahan masalah matematis siswa belum berkembang secara optimal dan juga proses pembelajaran matematika di kelas jarang menggunakan model pembelajaran yang lebih mengoptimalkan keaktifan siswa, guru hanya memusatkan proses pembelajaran dengan metode konvensional yakni pembelajaran yang berpusat pada guru (teacher centered).

Berdasarkan uraian diatas salah satu upaya yang harus dilakukan untuk meningkatkan kemampuan pemecahan masalah matematis siswa adalah dengan menerapkan model pembelajaran berbasis masalah. Menurut (Arends, 2007) "Pembelajaran berbasis masalah dapat membantu peserta didik untuk mengembangkan ketrampilan berfikir dan mengatasi masalah, mempelajari peran-peran, dan menjadi pelajar mandiri. Jadi, pembelajaran berbasis masalah disini adalah salah satu proses pembelajaran yang melibatkan siswa dalam memecahkan suatu masalah melalui tahapan-tahapan yang menghubungkan masalah tersebut dengan pengetahuan yang dimiliki siswa.

Melalui pembelajaran berbasis masalah peserta didik tidak hanya dapat mempelajari konsep-konsep yang berhubungan dengan masalah, tetapi peserta didik juga dapat mempelajari metode ilmiah untuk memecahkan masalah tersebut. Dengan demikian model pembelajaran berbasis masalah dalam matematika dapat mendorong peserta didik untuk belajar mandiri, dan mencari pengetahuannya sendiri, sehingga peserta didik akan memperoleh pengalaman dari pembelajaran.

Berdasarkan pemaparan di atas maka peneliti berpandangan bahwa perlu pengkajian mendalam mengenai "Pengaruh Model Pembelajaran Berbasis Masalah dalam Meningkatkan Kemampuan Pemecahan Masalah Matematis Siswa pada Materi Garis dan Sudut Kelas VII SMP Negeri 2 Dewantara"

Polya (Hendriana, Rohaeti, \& Sumarmo, 2018) mengemukakan bahwa pemecahan masalah adalah suatu usaha mencari jalan keluar dari suatu tujuan yang tidak begitu mudah segera dapat dicapai. Ruseffendi (Hendriana, Rohaeti, \& Sumarmo, 2018) menyatakan bahwa, sesuatu itu merupakan masalah bagi seseorang bila sesuatu itu merupakan hal baru bagi yang bersangkutan dan sesuai dengan kondisi atau tahap perkembangan mentalnya dan ia memiliki pengetahuan prasyarat yang mendasari. Dari beberapa ahli yang telah mengemukakan pendapatnya dapat disimpulkan bahwa pemecahan masalah adalah salah satu kemampuan dasar matematika yang harus dikuasai siswa untuk memecahkan masalah 
matetematis yang meliputi prosedur, dan strategi yang merupakan proses inti dan utama sebagai jantung matematika.

Indikator kemampuan pemecahan masalah matematis siswa menurut (Kennedy, Leonard, Tipps, Steve, \& Art, 2008) menyarankan empat langkah proses pemecahan masalah, yaitu: memahami masalah, merencanakan pemecahan masalah, melaksanakan pemecahan masalah, dan memeriksa kembali. Sedangkan menurut (Handayani, 2017) indikator kemampuan pemecahan masalah matematis yaitu:

1. Menunjukkan pemahaman masalah, meliputi kemampuan mengidentifikasi unsur-unsur yang diketahui, ditanyakan, dan kecukupan unsur yang diperlukan.

2. Mampu membuat atau menyusun model matematika, meliputi kemampuan merumuskan masalah situasi sehari-hari dalam matematika.

3. Memilih dan mengembangkan strategi pemecahan masalah, meliputi kemampuan memunculkan berbagai kemungkinan atau alternatif cara penyelesaian rumus-rumus atau pengetahuan mana yang dapat digunakan dalam pemecahan masalah tersebut.

4. Mampu menjelaskan dan memeriksa kebenaran jawaban yang diperoleh, meliputi kemampuan mengidentifikasi kesalahan-kesalahan perhitungan, kesalahan penggunaan rumus, memeriksa kecocokan antara yang telah ditemukan dengan apa yang ditanyakan dan dapat menjelaskan kebenaran jawaban tersebut.

Berdasarkan beberapa pendapat diatas, Indikator pemecahan masalah matematis siswa yang digunakan dalam penelitian ini adalah: (1) memahami masalah, (2) merencanakan atau merancang strategi pemecahan masalah, (3) melaksanakan penyelesaian dan (4) memeriksa kembali kebenaran hasil atau solusi.

Pembelajaran berbasis masalah termasuk salah satu model pembelajaran yang sangat populer. Menurut Arends (Anas, 2017) pembelajaran berbasis masalah merupakan suatu pendekatan pembelajaran, yang mana siswa mengerjakan permasalahan yang otentik dengan maksud untuk menyusun pengetahuan mereka sendiri, mengembangkan inkuiri dan keterampilan berfikir tingkat lebih tinggi, mengembangkan kemandirian dan percaya diri. Sedangkan menurut Tan (Rusman, 2016), pembelajaran berbasis masalah merupakan penggunaan berbagai macam kecerdasan yang diperlukan untuk melakukan konfrontasi terhadap tantangan dunia nyata, kemampuan untuk menghadapi segala sesuatu yang baru dan kompleksitas yang ada. Berdasarkan uraian diatas, dapat disimpulkan bahwa model pembelajaran berbasis masalah merupakan model pembelajaran yang di dalamnya terdapat rangkaian aktivitas yang dilakukan baik secara kelompok atau secara individual dalam memecahkan suatu permasalan yang berkaitan dengan dunia nyata yang menuntut siswa untuk berpikir, berkomunikasi, mencari dan meyelesaikan masalah dengan berpikir secara ilmiah

Pembelajaran berbasis masalah terdiri dari lima tahap yang dimulai dari guru memperkenalkan siswa dengan situasi masalah dan di akhiri dengan penyajian dan analisis hasil kerja siswa. Ibrahim dkk (Rusman, 2016) mengumukakan bahwa langkah-langkah Pembelajaran Berbasis Masalah sebagai berikut: 


\section{Tabel 1.1 Langkah-langkah Pembelajaran Berbasis Masalah}

\begin{tabular}{|c|c|c|}
\hline Fase & Indikator & Tingkah Laku Guru \\
\hline 1 & $\begin{array}{l}\text { Orientasi siswa pada } \\
\text { masalah }\end{array}$ & $\begin{array}{l}\text { Menjelaskan tujuan pembelajaran, menjelaskan logistik } \\
\text { yang diperlukan, dan memotivasi siswa terlibat pada } \\
\text { aktivitas pemecahan masalah }\end{array}$ \\
\hline 2 & $\begin{array}{l}\text { Mengorganisasi siswa } \\
\text { untuk belajar }\end{array}$ & $\begin{array}{l}\text { Membantu siswa mendefinisikan dan mangorganisasikan } \\
\text { tugas belajar yang berhubungan dengan masalah tersebut }\end{array}$ \\
\hline 3 & $\begin{array}{l}\text { Membimbing } \\
\text { pengalaman } \\
\text { individual/kelompok }\end{array}$ & $\begin{array}{l}\text { Mendorong siswa untuk mengumpulkan informasi yang } \\
\text { sesuai, melaksanakan eskperimen untuk mendapatkan } \\
\text { penjelasan dan pemecahan masalah }\end{array}$ \\
\hline 4 & $\begin{array}{l}\text { Mengembangkan dan } \\
\text { menyajikan hasil } \\
\text { karya }\end{array}$ & $\begin{array}{l}\text { Membantu siswa dalam merencanakan dan menyiapkan } \\
\text { karya yang sesuai seperti laporan, dan membantu mereka } \\
\text { untuk berbagai tugas dengan temannya }\end{array}$ \\
\hline 5 & $\begin{array}{l}\text { Menganalisis dan } \\
\text { mengevaluasi proses } \\
\text { pemecahan masalah }\end{array}$ & $\begin{array}{l}\text { Membantu siswa untuk melakukan refleksi atau evaluasi } \\
\text { terhadap penyelidikan mereka dan proses yang mereka } \\
\text { gunakan }\end{array}$ \\
\hline
\end{tabular}

Sumber: (Rusman, 2016)

\section{Metode Penelitian}

\section{Jenis Penelitian}

Penelitian ini menggunakan pendekatan kuantitatif. Adapun jenis penelitian yang dipergunakan adalah penelitian eksperimen semu (quasi eksperiment) dengan Non-equivalent control group desaign.

\section{Waktu dan Tempat Penelitian}

Penelitian ini dilaksanakan di SMPN 2 Dewantara Kab. Aceh Utara. Waktu penelitian ini berlangsung pada semester genap tahun ajaran 2019/2020.

\section{Populasi/ Sampel}

Populasi dalam penelitian ini adalah seluruh siswa kelas VII SMP NEGERI 2 DEWANTARA tahun ajaran 2019/2020. Sedangkan Sampel dalam penelitian adalah siswa kelas VIIA dan siswa kelas VIIB.

\section{Prosedur}

Pengolahan data diawali dengan menguji persyaratan statistik yang diperlukan sebagai dasar pengujian hipotesis, antara lain adalah ujii normalitas data, uji homogenitas, dan uji-t. Seluruh pengujian statistik menggunakan bantuan program komputer SPSS 18 dan Microsoft office excel 2007. Sedangkan untuk melihat peningkatan kemampuan pemecahan masalah matematis siswa menggunakan nilai $N$ Gain. 


\section{Data, Instrumen, dan Teknik Pengumpulan Data}

Adapun instrumen penelitian yang akan digunakan dalam penelitian ini adalah tes kemampuan pemecahan masalah matematis siswa yang terdiri dari 4 soal berbentuk uraian pada materi garis dan sudut serta lembar observasi. Soal ini yang akan digunakan dalam pretest dan posttest. Instrumen tes diujicobakan terlebih dahulu untuk melihat kelayakan berdasarkan tingkat validitas, reliabilitas, daya pembeda dan tingkat kesukaran pada setiap butir soal.

\section{Hasil dan Pembahasan}

Berdasarkan hasil pretest dan posttest yang dilakukan diperoleh data sebagai berikut:

Tabel 4.1 Statistik Deskriptif Kemampuan Pemecahan Masalah Matematis Siswa

\begin{tabular}{|c|c|c|c|c|c|c|c|c|c|c|}
\hline \multirow[b]{2}{*}{ Nilai } & \multicolumn{5}{|c|}{ Kelas Eksperimen } & \multicolumn{5}{|c|}{ Kelas Kontrol } \\
\hline & $\mathbf{N}$ & $\mathbf{X}_{\min }$ & $\underset{\mathrm{s}}{\mathbf{X}_{\text {mak }}}$ & $\bar{x}$ & $\mathbf{S}$ & $\mathbf{N}$ & $\mathbf{X}_{\min }$ & $\underset{\mathbf{s}}{\mathbf{X}_{\text {mak }}}$ & $\bar{x}$ & $\mathbf{S}$ \\
\hline $\begin{array}{c}\text { Pre- } \\
\text { test }\end{array}$ & 22 & 1 & 3,75 & 3,18 & 0,690 & 22 & 1,50 & 6,50 & 3,27 & 1,825 \\
\hline $\begin{array}{c}\text { Postte } \\
\text { st }\end{array}$ & 22 & 4,75 & 10 & 8,90 & 1,194 & 22 & 2,25 & 10 & 5.79 & 2,773 \\
\hline $\mathrm{N}$-gain & 22 & 0,19 & 1,00 & 0.8381 & 0,1809 & 22 & 0,03 & 1,00 & $\begin{array}{c}0,419 \\
1\end{array}$ & 0,350 \\
\hline
\end{tabular}

Tabel 4.1 memperlihatkan bahwa skor minimum Pre-test kemampuan pemecahan masalah matematis siswa di kelas eksperimen adalah 1, dan kelas kontrol memperlihatkan nilai minimum 1,50 , sedangkan skor maksimum kemampuan pemecahan masalah matematis siswa kelas eksperimen adalah 3,75, dan kelas kontrol memperlihatkan nilai maksimum 6,50. Pada Posttest skor minimum kelas eksperimen dengan skor 4,75 lebih tinggi dibandingkan skor minimum kelas kontrol dengan skor 2,25 dan skor maksimum kemampuan pemecahan masalah matematis siswa untuk kelas eksperimen dan kelas kontrol mempunyai skor sama yaitu 10 .

Skor rerata pre-test siswa kemampuan pemecahan masalah matematis siswa kelas eksperimen dengan perolehan skor 3,1818 lebih rendah dibanding rerata pre-test siswa untuk kelas kontrol dengan perolehan skor 3,2727. Sedangkan skor rerata posttest siswa setelah proses pembelajaran untuk kelas eksperimen dengan skor rerata posttes 8,9091 lebih tinggi dibanding kelas kontrol dengan skor rerata posttest 5,7954. Simpangan baku pre-test siswa 
kemampuan pemecahan masalah matematis untuk kelas eksperimen dengan skor 0,690 lebih rendah dibanding simpangan baku pre-test untuk kelas kontrol dengan skor 1,825. Simpangan baku posttest siswa kemampuan pemecahan masalah matematis untuk kelas eksperimen dengan skor 1,194 juga lebih rendah dibanding simpangan baku posttest siswa kelas kontrol dengan skor 2,773 .

Rata-rata $N$-Gain yang merupakan gambaran peningkatan kemampuan pemecahan masalah matematis dengan model pembelajaran berbasis masalah maupun dengan pembelajaran konvensional selengkapnya dapat dilihat pada table berikut:

Tabel 4.2 Data Rerata N-Gain Kemampuan Pemecahan Masalah

\begin{tabular}{lccccc}
\hline \multicolumn{1}{c}{ Kelas } & \multicolumn{5}{c}{ Data skor $\mathbf{N}-$ Gain } \\
Eksperimen & $\mathbf{X}_{\min }$ & $\mathbf{X}_{\max }$ & $\overline{\boldsymbol{X}}$ & $\mathbf{S}$ & Kategori \\
Kontrol & 0,19 & 1,00 & 0,8381 & 0,18097 & Tinggi \\
\hline
\end{tabular}

Berdasarkan Tabel 4.2 di atas diperoleh bahwa skor $N$-Gain minimum data kelas eksperimen dengan skor 0,19 lebih tinggi daripada $N$-Gain minimum kelas kontrol dengan skor 0,03 sedangkan N-Gain maksimum kelas eksperimen dengan skor 1,00 sama dengan $N$-Gain maksimum kelas kontrol dengan skor 1,00. Simpangan baku skor $N$-Gain kemampuan pemecahan masalah matematis siswa kelas eksperimen dengan skor 0,18097 lebih rendah dibandingkan dengan skor $\mathrm{N}$-Gain kemampuan pemecahan masalah matematis siswa kelas kontrol dengan skor 0,35052 , artinya skor $N$-Gain kemampuan pemecahan masalah matematis siswa kelas eksperimen dan kelas kontrol sama-sama menyebar.Untuk skor rata-rata $\mathrm{N}$-Gain lebih jelas dapat dilihat pada gambar berikut:

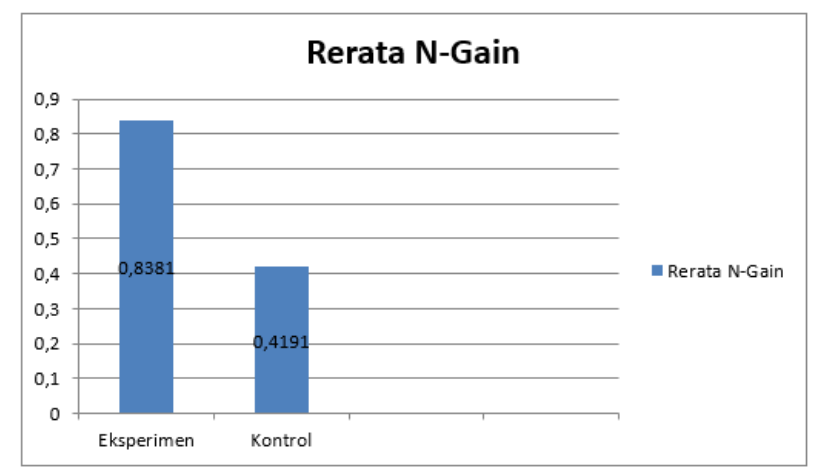

Gambar 4.1 Diagram Rerata N-Gain Kemampuan Pemecahan Masalah

Pada gambar 4.1 diatas dapat dilihat bahwa rerata $N$-Gain kemampuan pemecahan masalah matematis siswa pada kelas eksperimen dengan skor 0,8381 terlihat lebih tinggi dibandingkan dengan rerata skor $N$-Gain kelas kontrol dengan skor 0,4191.

Setelah dilakukan pengolahan data, nilai signifikansi (Asymp. sig. 2-tailed) dengan uji Mann-Whitney $U$ adalah 0,000 . Setengah dari nilai signifikansi ini $\frac{1}{2}(0,000)=0,000$ lebih kecil dari 0,05 maka $\mathrm{H}_{0}$ ditolak, peningkatan kemampuan pemecahan masalah matematis 


\section{Vol 1, Nomor 1, Mei 2021}

siswa dengan model pembelajaran berbasis masalah lebih baik daripada siswa yang menggunakan model konvensional

Hal tersebut memberikan gambaran bahwa pembelajaran dengan menerapkan model pembelajaran berbasis masalah dapat meningkatkan kemampuan pemecahan masalah matematis siswa. Hasil penelitian ini seajalan dengan hasil peneliti-peneliti sebelumnya, seperti penelitian yang dilakukan (Handayani, 2017), menyatakan bahwa kemampuan pemecahan masalah matematis siswa yang memporoleh pembelajaran berbasis masalah lebih baik daripada kemampuan pemecahan masalah matematis siswa yang memperoleh pembelajaran konvensional.

\section{Kesimpulan}

Berdasarkan hasil penelitian dapat disimpulkan bahwa, peningkatan kemampuan pemecahan masalah matematis siswa yang diajarkan melalui model pembelajaran berbasis masalah lebih baik dari pada model konvensional di SMPN 2 Dewantara Kab. Aceh Utara.

\section{DAFTAR PUSTAKA}

Anas, M. (2017). Pengaruh Penerapan Model Pembelajaran Berbasis Masalah (Problem Based Learning) terhadap Hasil Belajar Peserta Didik Kelas IV MIN Sepabatu Kecamatan Tinambung Kabupaten Polewali Mandar. Sulawesi Selatan: Prodi Pendidikan Guru Madrasah Ibtidaiyah Fakultas Tarbiyah dan Keguruan UIN Alauddin Makassar.

Arends, R. I. (2007). Learning To Teach. New York: McGraw-Hill.

Arikunto, S. (2006). Prosedur Penelitian Suatu Pendekatan Praktek. Jakarta: PT Rineka Cipta.

Handayani, D. (2017). Pengaruh Model Problem Based Learning Terhadap Kemampuan Pemecahan Masalah Matematis Siswa di Kelas VIII MTS S Al-Washliyah Tahun Ajaran 2016/2017. Sumatera Utara: Jurusan Pendidikan Matematika Fakultas Ilmu Tarbiyah dan Keguruan UINSU.

Hendriana, H., Rohaeti, E. E., \& Sumarmo, U. (2018). Hard Skills dan Soft Skills Matematik Siswa. Bandung: PT Aditama.

Kennedy, Leonard, M., Tipps, Steve, \&. J., \& Art. (2008). Guiding Children's Learning of Mathematics. Belmont, USA: Thomson Wadsworth.

NCTM. (2000). Principles and Standards for School Mathematics $\square$ NCTM.

Rusman. (2016). Model-Model Pembelajaran Mengembangkan Profesionalisme Guru. Jakarta: PT Raja grafindo Persada. 